The FASEB Journal express article 10.1096/fj.00-0891fje. Published online June 8, 2001.

\title{
Convertases other than furin cleave $\beta$-secretase to its mature form
}

Inga Pinnix $^{1 @}$, Jenny E. Council ${ }^{1 @}$, Beverly Roseberry $^{1}$, Luisa Onstead ${ }^{1}$, William Mallender ${ }^{2}$, Joseph Sucic $^{3}$, and Kumar Sambamurti ${ }^{1 *}$

${ }^{\circledR}$ These authors contributed equally.

${ }^{1}$ Department of Neuroscience, Mayo Clinic, 4500 San Pablo Road, Jacksonville, FL 32224

${ }^{2}$ Current address: Millennium Pharmaceuticals, Inc., 270 Albany St., Cambridge, MA 02139

${ }^{3}$ Biology Department, University of Michigan-Flint, 303 East Kearsley St., Flint, MI 48502

*Corresponding author: Kumar Sambamurti, Ph.D., Department of Neuroscience, Mayo Clinic, 4500 San Pablo Road, Jacksonville, FL 32224. E-mail: samba@mayo.edu.

\section{ABSTRACT}

An aspartyl protease, Beta-Site APP cleaving enzyme (BACE), was identified as the $\beta$-secretase responsible for generating the Amyloid $\beta$ protein that is believed to cause Alzheimer's disease. BACE has a short propeptide domain that is absent in the mature enzyme because of proteolytic cleavage after the sequence RLPR. This sequence is a predicted substrate for proprotein convertases such as furin. To determine the role of furin and other proprotein convertases, we expressed proBACE in a furin-deficient mutant Chinese hamster ovary (CHO-K1) line, RPE.40. ProBACE signal was higher in RPE.40 than in the CHO-K1 parent, which confirmed that furin plays a role in propeptide removal. However, two independent approaches showed that proBACE is cleaved to mature BACE in RPE.40: proBACE was rapidly turned over in RPE.40 although total BACE was stable, and decanoyl-RVKR-chloromethylketone, an inhibitor of the proprotein convertase family, substantially increased proBACE levels in both RPE.40 and CHOK1. Transient transfection shows that furin, PACE4, PC5/6, and PC7 mediate BACE cleavage in vivo, at least when overexpressed. RPE.40 is proficient in BACE activity despite its furin deficiency. Therefore, our finding that proBACE is cleaved in this mutant leaves open the possibility that maturation is an important regulatory step and a therapeutic target.

Key words: proprotein convertases $\bullet$ memapsin $\bullet$ aspartyl proteases $\bullet$ proprotein convertases $\bullet$ $\mathrm{BACE} \bullet$ zymogen activation $\bullet$ amyloid $\bullet$ Alzheimer

The 38-43 residue peptide Amyloid $\beta$ (A $\beta)$, invariably deposited in the Alzheimer's disease (AD) brain, is derived from a larger precursor, Amyloid $\beta$ protein precursor (APP), as summarized below (1-6). A $\beta$ secreted from cultured cells, in the plasma and cerebrospinal fluid of normal individuals, is mostly 40 residues (A $\beta 40)$, but a small population $(\sim 10 \%)$ is $42-43$ residues long (A $\beta 42)(7-10)$. Familial AD (FAD) mutations on APP, presenilin 1 (PS1), and presenilin 2 (PS2) increase levels of $A \beta 42$, making the reduction of $A \beta$, primarily $\mathrm{A} \beta 42$, an important therapeutic goal (11). 
$\mathrm{A} \beta$ is produced by sequential cleavage of APP by proteases named $\beta$ - and $\gamma$-secretases. $\beta$ Secretase cleaves at the amino terminal end of the $A \beta$ sequence, producing a secreted derivative, sAPP $\beta$ (the $N$-terminal fragment of APP cleaved before A $\beta$ residue 1) (12) and the A $\beta$-bearing $C$-terminal fragment of 99 residues, CTF $\beta$ (the membrane-anchored $C$-terminal fragment of APP starting at $\mathrm{A} \beta$ residue 1) (13). The importance of $\beta$-secretase in $\mathrm{AD}$ is demonstrated by the finding that $A \beta$ and $C T F \beta$ levels are specifically increased in the FAD mutant APP derivative that replaces KM at residues 670-1 in wild-type APP (APP $\left.{ }_{\mathrm{WT}}\right)$ with $\mathrm{NL}\left(\mathrm{APP}_{\mathrm{SW}}\right)(14)$.

A novel pepstatin A-insensitive aspartyl protease, Beta-Site APP cleaving enzyme (BACE), was identified as the $\beta$-secretase that cleaves at positions 1 and 11 of the A $\beta$ sequence (15-19). $\mathrm{BACE}$ cleaves $\mathrm{APP}_{\mathrm{SW}}$ more efficiently than $\mathrm{APP}_{\mathrm{WT}}$ in vitro, a result that is consistent with the higher levels of $A \beta$ and CTF $\beta$ generated from cells expressing this mutant APP substrate. A homologue of BACE, BACE2, was also found, but this enzyme prefers to cleave within the A $\beta$ sequence, making it relevant only in some rare mutant APP forms (20). Protein phosphorylation (21) and glycosylphosphatidylinnositol-anchored proteins (22) regulate A $\beta$ biogenesis and $\beta$ secretase processing of APP. An alternative activity, $\alpha$-secretase, cleaves APP within A $\beta$ (between residues 16 and 17) to the larger secreted derivative, sAPP $\alpha$ (the $N$-terminal fragment of APP cleaved before A $\beta$ residue 16) (23) and membrane-associated 83-residue fragment, CTF $\alpha$ (the membrane-anchored $C$-terminal fragment of APP starting at A $\beta$ residue 17) (13). A family of disintegrin metalloproteases, such as the tumor necrosis factor alpha converting enzyme (TACE) and the Adamalysins, ADAM 10, has been implicated in $\alpha$-secretase cleavage of APP (24-26). The $\alpha$-secretase pathway is regulated by protein phosphorylation (21). Cleavage of CTF $\beta$ and CTF $\alpha$ by $\gamma$-secretase generates A $\beta$ and a smaller fragment of 24-26 residues called P3, respectively. Cleavage by $\gamma$-secretase also releases a soluble $C$-terminal fragment, CTF $\gamma$ (the soluble $C$-terminal fragment generated by $\gamma$-secretase cleavage after A $\beta 40 / 42$ ), although this fragment is generally not detected in cell lysates, presumably because of sequestration or rapid turnover (27). A combination of several studies indicates that PS1 and PS2 are the active subunits of $\gamma$-secretase (28-30). Consistent with this notion, knockout animals deficient in PS1 and PS2 are deficient in $\gamma$-secretase activity $(31,32)$.

Recently, knockout mice lacking BACE were generated, and their viability makes BACE a good therapeutic candidate for lowering $\mathrm{A} \beta$ in the $\mathrm{AD}$ brain. These BACE-deficient mice were deficient in $\mathrm{A} \beta$ production in the brain and in isolated neurons, a result suggesting that BACE is the major $\beta$-secretase activity in the brain (33). However, the question of compensation by alternative activities that lower $A \beta$ by cleavage within $A \beta$, for example by BACE2, has not yet been examined (20).

The BACE cDNA sequence reveals an integral membrane aspartyl protease with an $N$-terminal signal sequence (residues 1-21) followed by a large luminal catalytic domain, a single transmembrane domain (residues 461-477), and a short cytoplasmic domain (residues 478-501). However, the purified BACE protein began at residue 46, which indicates that a stretch of basic residues (prodomain; residues 22-45) is proteolytically removed in mature BACE (17). Thus, proBACE is a zymogen with a 24-residue prodomain whose function has not yet been fully characterized. Creemers et al. have suggested that proBACE is active in vivo, making the maturation process irrelevant (34). However, this view does not fit the known zymogen 
activation process for other aspartyl proteases and in vitro findings that recombinant proBACE shows increased activity when portions of its prodomain were removed by clostripain cleavage in vitro (35). One of the fragments starting at residue G59 was threefold more active than proBACE (35). A similar threefold increase in BACE activity upon prodomain removal by in vitro cleavage at the authentic site, E46, was also recently reported (36). Thus, the enzymes that cleave proBACE may be useful therapeutic targets and help us to understand how BACE activity is regulated through maturation.

The sequence at the cleavage site for proBACE cleavage is RPLR $\downarrow$, which follows the rules for cleavage by subtilisin-like proprotein convertases that cleave after the recognition motif K/R-Xn$\mathrm{R}$, where $n=0,2,4$, or 6 and $\mathrm{X}$ is any amino acid except cysteine (37). However, the sequence deviates from the typical cleavage sequence of $\mathrm{K} / \mathrm{R}-\mathrm{X}-\mathrm{K} / \mathrm{R}-\mathrm{R}$ in that it lacks a basic residue in the P2 position (38). There are seven known proprotein convertases: furin, PC1/3, PC2, PACE4 (paired amino acid cleaving enzyme 4), PC4, PC5/6, and PC7. Of these, furin, PACE4, PC5/6, and PC7 are most widely expressed in the constitutive secretory pathway $(37,38)$. Although all these enzymes share a similar cleavage-sequence motif, they have distinct substrate preferences. For example, LoVo cells that are deficient in furin are incapable of cleaving Newcastle disease virus fusion glycoprotein but cleave Human Immunodeficiency Virus envelope protein, GP160, as efficiently as normal cell lines (39).

The basis for differences in substrate specificity and the rules for cleavage of specific substrates by specific convertases have not yet been determined; therefore, we needed to empirically determine the role of each proprotein convertase in the maturation of a proprotein. We used a mutant Chinese hamster ovary (CHO-K1) line deficient in furin, RPE.40, to determine the role of furin and other convertases in the cleavage of proBACE (40). Extensive analysis has shown that both alleles of furin are defective, which results in a furin null phenotype in this cell line (41, 42). Furin will efficiently cleave both Arg-X-(Lys/Arg)-Arg and Arg-X-X-Arg motifs, whereas PACE4 at least prefers substrates with a basic residue in the P2 position (43). Because the cleavage site in BACE lacks a basic residue at the P2 position, furin is the likely candidate proBACE-processing enzyme. However, the data presented in this study show that proBACE maturation does take place in the RPE.40 cell line, which suggests that other activities can mediate BACE maturation.

\section{MATERIALS AND METHODS}

\section{Reagents}

All reagents were from VWR Scientific (West Chester, PA) and were the highest grade available unless specified otherwise. The proprotein convertase inhibitor, decanoyl RVKR chloromethylketone (d-RVKR-CMK) was from Peptides International (Gaithersburg, MD).

\section{Plasmids and constructs}

The BACE cDNA was amplified from a human brain cDNA library (Edge Biosystems, Gaithersburg, MD) using the high-fidelity polymerase, PFX (Invitrogen, Carlsbad, CA), and the primers: 5' AGC TCC CTC TCC TGA GAA G and 5' TCA GTG GTG GTG GTG GTG GTG 
CTT CAG CAG GGA GAT GTC. The amplified cDNA encoding BACE tagged with sixhistidine residues at its $C$-terminus was cloned into an intermediate vector pTZ18U, subcloned into pCDNA3.1zeo (Invitrogen), and confirmed by sequence analysis at the Mayo Clinic molecular biology core facility. Furin and PACE4 expressing constructs have been described previously (43). PC5/6 and PC7 were obtained by searching the expressed sequence tag databases for full-length clones (GenBank: AW412393 and AA104955), purchased from the American type culture collection (ATCC) and confirmed by sequence analysis. The PC5/6 and PC7 cDNAs were already cloned in pSPORT-derived expression vectors under the human cytomegalo-virus early promoter.

\section{Cell culture and transfection}

The furin-deficient cell line, RPE.40, was a gift from Dr. Thomas Moehring (University of Vermont, Burlington, VT, retired). This cell line is incapable of cleaving Pseudomonas exotoxin to its toxic mature form and is deficient in the maturation of several proproteins $(40-43,44,45)$. The wild-type CHO-K1 parent was from ATCC (CCL-61). CHO-K1 and RPE.40 were maintained in OPTI-MEM (Invitrogen), supplemented with 5\% fetal bovine serum (FBS; HyClone, Logan, UT) and incubated for assays in CCM5 (HyClone). CHO-K1 and RPE.40 were transfected with Lipofectamine as described (Invitrogen), and stable cell lines expressing BACE (CHO-K1-BACE and RPE.40-BACE) were generated. Where relevant, cells were transiently transfected with appropriate plasmids expressing the proprotein convertases under the human cytomegalovirus promoter, and cells were collected $48 \mathrm{~h}$ after completion of the transfection. To avoid the accidental selection of wild-type cells, we tested the RPE.40-BACE cell line for sensitivity to Pseudomonas exotoxin. The wild-type CHO-K1 cells were highly sensitive to Pseudomonas exotoxin, resulting in complete cell death and its loss from the culture dishes, whereas RPE.40-BACE remained resistant as expected for a furin-deficient culture (data not shown). CHO-K1, RPE.40, and their transfected derivatives were all similar in growth rate and plating efficiency.

\section{Antibodies}

Polyclonal antibodies against PACE4 and PC7 were from Alexis Biologicals (San Diego, CA), and antifurin was from Santa Cruz Biotechnology (Santa Cruz, CA). Three rabbit antibodies were raised against BACE using peptides derived from the proregion (residues 26-45), the $\mathrm{N}$ terminal end of the mature protein (residues 46-65), and the $C$-terminal 15 residues. The peptides $\quad \mathrm{BACE}_{26-45} \quad$ C-IRLPLRSGLGGAPLGLRLPR, BACE $_{46-65}$ ETDEEPEEPGRRGSFVEMVD-C, and BACE ${ }_{\mathrm{CT} 15} \mathrm{C}-\mathrm{RQQHDDFADDISLLK}$ were synthesized at the Mayo Clinic protein core facility with terminal cysteine residues as indicated and coupled to maleimide-activated keyhole limpet hemocyanin (Pierce, Rockford, IL). Antibodies were raised at Cocalico Biologicals (Reamstown, PA) using a custom schedule, and the sera provided were tested by Western blot analysis as previously described (46). Antibodies against BACE $26-45$ will not detect mature BACE, because the peptide is derived from the proregion of BACE that is lost upon proteolytic maturation (Fig. 1). BACE $_{46-65}$ represents the first 20 residues of mature $\mathrm{BACE}$ and is against its extracellular domain, and $\mathrm{BACE}_{\mathrm{CT} 15}$ is against the last 15 residues of its cytoplasmic domain. 
Transfected RPE.40 cells expressing BACE alone or BACE + furin were seeded into six-well dishes at $4 \times 10^{5}$ cells/well and allowed to grow to near confluence for one day. The medium was replaced with RPMI lacking cysteine and methionine for $10 \mathrm{~min}$, and cells were incubated for an additional $45 \mathrm{~min}$ in the same medium containing $200 \mu \mathrm{Ci} /$ well of a mixture of cysteine and methionine ( $\operatorname{Tran}^{35}$ Slabel; ICN; Costa Mesa, CA). The radioactive medium was aspirated and replaced with CCM5 for the indicated chase time. Cells were lysed in MPER (Pierce), adjusted to RIPA (47), and immunoprecipitated using protein-A beads and a non-immune antiserum to reduce background. The supernatant was divided into two parts, precipitated with $\mathrm{BACE}_{26-45}$ and BACE $_{\mathrm{CT} 15}$ in RIPA buffer overnight, and separated on $4-15 \%$ polyacrylamide gels (Biorad, Richmond, CA). Western blot analyses of media and lysates were conducted and quantified as described previously using precast 10\% NuPAGE (Invitrogen) or Biorad 4-15\% gels (46). All quantitative data are based on the analysis of three or more independent samples as previously described (22).

\section{RESULTS AND DISCUSSION}

\section{BACE propeptide cleavage is reduced in a furin-deficient cell line}

Analysis of the BACE protein sequence by Generunner (Hastings Software, Inc., Hastings, NY) and PSORT (http://psort.nibb.ac.jp/) reveals a 21-residue signal sequence cleaved by signal peptidase in the endoplasmic reticulum (ER). The proBACE protein starting at residue 22 is a type-I integral membrane protein with a large extracellular (catalytic) domain, a single transmembrane domain, and a short cytoplasmic tail (i․ $1 \mathrm{~A})$. The $24 \mathrm{~N}$-terminal residues are post-translationally removed, and the purified mature BACE starts at residue 46 (17). Note that immature and mature BACE in the remaining text refer to the proteolytic removal of the 24residue prodomain and not its glycosylation states, which are described later.

We transfected CHO-K1 and its furin-deficient derivative, RPE.40, with vector control or BACE and analyzed lysates from three independent stable clones by Western blotting with antibodies against peptides corresponding to proBACE $\left(\mathrm{BACE}_{26-45}\right)$ and total (pro + mature) $\mathrm{BACE}$ $\left(\mathrm{BACE}_{46-65}\right.$ and $\mathrm{BACE}_{\mathrm{CT} 15}$; Fig. 1). The three antibodies detect a strong BACE band of 75-kDa in lysates from transfected RPE.40 and CHO-K1 cell lines (Fig. 1B-D) and a fainter 65-kDa band (Fig. 2). Endoglycosidase F (Endo F) deglycosylates both 65- and 75-kDa bands to a single $50-\mathrm{kDa}$ band, indicating that the two species represent alternative glycosylation states of a single protein (Fig. 2). The $65-\mathrm{kDa}$ band is sensitive to endoglycosidase $\mathrm{H}$ (Endo $\mathrm{H}$ ) and therefore represents the core glycosylated ER form of BACE, whereas the 75-kDa band is resistant, indicating that its $N$-linked sugars have been elaborated to complex forms after trafficking through the secretory pathway. The proBACE signal is stronger in lysates of three independent clones from RPE.40 cells than in the parental CHO-K1, although the range of total BACE signal detected by $\mathrm{BACE}_{46-65}$ and $\mathrm{BACE}_{\mathrm{CT} 15}$ is similar in the two cell types (Fig. 1B). Thus, BACE maturation is reduced in RPE.40 cells, in agreement with previous studies concluding that furin is involved in this process $(34,48)$.

\section{BACE propeptide is cleaved in RPE.40}


Although BACE cleavage is reduced in RPE.40, we did not observe a reduction in CTF $\beta$ or secreted A $\beta$ compared with the parental line. Initially, we interpreted this to mean that proBACE was active in vivo (34 and our unpublished observations). However, in contrast to our expectations, proBACE signal on Western blots was rapidly lost $(<1 \mathrm{~h})$ in lysates from cycloheximide-treated RPE.40-BACE cells, whereas the total BACE signal remained unchanged for up to $8 \mathrm{~h}$ (data not shown). These findings argue that BACE maturation continues in the mutant RPE.40 cells and are consistent with reports that BACE is a relatively stable protein with a half-life of $16 \mathrm{~h}$ (49). As indicated in Experimental Procedures, the maturation observed is not due to the accidental selection of wild-type cells, because RPE.40-BACE was resistant to Pseudomonas exotoxin as expected (40).

To confirm the rapid turnover of proBACE in RPE.40, we conducted a pulse-chase study in which transfected RPE.40 cells expressing BACE or co-expressing BACE + furin were metabolically labeled with $\operatorname{Tran}^{35}$ Slabel for $45 \mathrm{~min}$ and chased for $0,0.5,1$, and $2 \mathrm{~h}$. As expected for a glycosylated protein, BACE starts out as the smaller $65-\mathrm{kDa}$ core-glycosylated band at zero time of chase that matures into a larger 75-kDa band during the chase (Fig. 3A, B). Both bands were precipitated with the $\mathrm{BACE}_{26-45}$ antibody in the RPE.40-BACE cells, but only the 65-kDa core glycosylated protein was precipitated in the RPE.40-BACE-furin culture (Fig. 3A). The signal of proBACE was reduced after $1 \mathrm{~h}$ and almost completely lost after $2 \mathrm{~h}$ of chase in RPE.40-BACE. The turnover of proBACE was faster in RPE.40-BACE-furin transfected with both BACE and furin (Fig. 3A). In contrast, the signal for fully glycosylated BACE increased through the duration of the chase $(2 \mathrm{~h})$ when immunoprecipitated with BACE $\mathrm{CT}_{15}$ (Fig. $\left.3 \mathrm{~B}\right)$. The rapid turnover of proBACE signal in RPE.40, together with the stability of total BACE, indicates that BACE is cleaved in RPE.40-BACE, albeit at a slower rate than in RPE.40-BACE-furin.

To independently show that proBACE is cleaved in RPE.40, CHO-K1-BACE and RPE.40BACE were treated for $4 \mathrm{~h}$ with an inhibitor of the proprotein convertases, d-RVKR-CMK, and lysates were examined for proBACE and mature BACE. With inhibitor treatment, the proBACE signal is drastically increased by more than ninefold in the parental $\mathrm{CHO}-\mathrm{K} 1$ and by more than 4.5-fold in RPE.40 (Fig. 4A, D). The increase of proBACE signal in the inhibitor-treated cells suggests that a proprotein convertase is responsible for the normal loss of the proBACE signal in both wild-type and furin-deficient cells. Total BACE signal was not altered by the inhibitor in either wild-type CHO-K1 or RPE.40, as shown by Western blotting with BACE $46-65$ (Fig. 4B, D) and $\mathrm{BACE}_{\mathrm{CT} 15}$ (Fig. 4C, D). The large increase in proBACE signal on inhibitor treatment indicates that it contributes little to the total BACE signal, allowing us to directly extend the data on total BACE to mature BACE. The observed increase of proBACE signal in the furin-deficient cell line when treated with a convertase inhibitor-without a similar effect on mature BACEsuggests that the prodomain continues to be processed in the absence of furin, thereby confirming the pulse-chase data (Fig. 3). In addition, the specificity of the inhibitor suggests that, in the absence of furin, other proprotein convertases are involved in BACE maturation.

\section{Several known proprotein convertases can cleave BACE to its mature form}

Accumulation of proBACE on treatment with brefeldin A, monensin, or A23187 (47 and data not shown) and inhibition with d-RVKR-CMK suggests that a calcium-dependent protease, such 
as a proprotein convertase, cleaves proBACE to its mature form in a late Golgi compartment. We therefore decided to test whether proBACE levels are reduced in RPE.40 cells transfected with furin, PACE4, PC5/6, and PC7, the convertases known to act in the constitutive secretory pathway. The data show that proBACE is reduced in cultures transfected with all these convertases (Fig. 5A). The levels of proBACE detected by $\mathrm{BACE}_{26-45}$ were significantly lower $(P<0.05$, two-tailed $t$ test) in RPE.40-BACE cells transfected with furin, PC7, and PC5/6 but more modest and not significant for PACE4 $(p=0.07)$, as shown by the graph in Figure 5D. Total BACE levels were not reduced by transfection with the proprotein convertases, as detected with BACE $_{46-65}$ (Fig. 5B) or BACE $\mathrm{CT}_{15}$ (Fig. 5C) and shown quantitatively in Figure 5D. If anything, there was an overall tendency toward an increase in levels with both antibodies (Fig. 5D), but this increase was not significant. After transient transfection, we were able to detect furin and PC7 expression using commercial antibodies (data not shown). Although good antibodies were not available against PACE4 and PC5/6, they should be expressed in the transiently transfected cells, as indicated by their ability to reduce the proBACE signal (Fig. 5). In summary, all the tested proprotein convertases specifically reduce proBACE signal without simultaneously decreasing total BACE (by extension, mature BACE). Thus, in agreement with the previous report (34), furin, PC7, PACE4, and PC5/6 appear to augment cleavage of BACE to its mature form—at least in transiently transfected cells expressing high levels of these enzymes.

Transfection with PC5/6 reduced levels of the faster, core glycosylated, Endo H-sensitive, 65$\mathrm{kDa}$ band of proBACE (Fig. 5A) that represents the ER pool of BACE as discussed earlier (Fig. 2). Because BACE maturation by the convertases should take place primarily in the Golgi, the $65-\mathrm{kDa}$ band is expected to contain more of the prodomain. Consistent with this prediction, the signal of the $65-\mathrm{kDa}$ band detected by the proBACE-specific antibody $\mathrm{BACE}_{26-45}$ (Fig. 5A) is higher than with the two antibodies against the mature domains of BACE (Fig. 5B, $\underline{\mathrm{C}}$ ). PC5/6 may at least partly cleave BACE before elaboration of the $N$-linked sugars, consistent with findings that proBACE cleavage starts in early secretory compartments (50).

Tang and co-workers found that furin did not cleave proBACE, but others have demonstrated in vitro cleavage of $\mathrm{BACE}$ by furin $(35,36,48)$. However, proBACE appears to be a poor substrate, based on the large amounts of furin needed for its cleavage in vitro $(36,48)$. In addition, the in vitro cleavage by purified furin does not rule out the possibility of contamination by another relevant protease, given that the recombinant furin (Affinity Bioreagents Golden, $\mathrm{CO}$ ) was isolated from an animal cell line, BSC-40 $(36,48)$. Thus, other proprotein convertases may be more important players than furin for proBACE processing in vivo. The furin-deficient RPE.40 cells are clearly capable of cleaving BACE very efficiently, as observed by the rapid turnover of proBACE. It is possible that cleavage may occur at alternative sites in this cell line, but this is unlikely because the antibodies $\mathrm{BACE}_{26-45}$ and $\mathrm{BACE}_{46-65}$ used in the study are against the few residues adjoining the start of mature BACE. RPE.40 cells expressed PACE4 RNA (43). Nevertheless, based on its failure to process several known proprotein convertase substrates, these cells do not show detectable PACE4, PC1/2, or PC5/6 activity (J. Sucic, unpublished observations).

The identity of the major protease responsible for BACE maturation in RPE.40 cells remains an important unanswered question. Based on reports that the major proprotein convertases in $\mathrm{CHO}-$ $\mathrm{K} 1$ cells are furin and PC7, the latter is a likely candidate (51). However, given the complexity of 
the proteolytic pathways in the cell, we cannot rule out the possibility that the BACE prodomain is cleaved by a protease that is activated by furin and other proprotein convertases. For example, membranes from RPE.40 transfected with PACE4 also contain a $\mathrm{Ca}++$ independent protease that cleaves HIV GP160 (50). Despite similarities in the substrate specificity of this protease, its lack of $\mathrm{Ca}++$ requirement points away from the subtilisin-like proprotein convertases (44).

While this manuscript was in preparation, two J. Biol. Chem. reports in press provided evidence for proBACE cleavage by furin $(34,48)$. One report indicated that the mutant RPE.40 cells are deficient in BACE maturation and that $\beta$-secretase activity was not reduced in transfected RPE.40 cells (34). Although the authors acknowledge the possibility that proBACE may be cleaved in RPE.40, they argue against it and suggest that this maturation event is physiologically irrelevant (34). Our studies show that, despite the furin deficiency, proBACE is converted to its mature form in RPE.40 cells. This result leaves open the possibility that proteolytic cleavage regulates $\beta$-secretase activity in the AD brain.

The difference in our findings may be due to the method for detection of proBACE (Western blotting with a specific proBACE antibody vs. separation of BACE by isoelectric focusing after a short label). Ideally, we need a cell line that fails to generate mature BACE to determine whether this maturation step is physiologically relevant for regulating $\beta$-secretase activity. Although peptide inhibitors (e.g., d-RVKR-CMK) of the proprotein convertase pathways are known, they are quite unstable, so it is difficult to use them in long-term studies. Given that mature BACE is very stable, we need to treat it with inhibitors for long periods to study the effects of eliminating it on $\beta$-secretase processing in vivo. In addition, these studies cannot really be conducted in transfected cells, because proBACE levels are increased by several orders of magnitude in transfected cells, which may prevent us from detecting the effect of increasing BACE activity by threefold following proteolytic maturation. The finding that proBACE activity is $66 \%$ lower than mature BACE generated by either furin or clostripain cleavage suggests that this pathway is capable of regulating BACE activity in vivo $(35,36)$. This level of inhibition should be physiologically relevant, considering that BACE cleavage of wild-type APP is limiting for $A \beta$ production and is the minor pathway for proteolytic processing of APP to secreted derivatives.

BACE is expected to be a good therapeutic target based on the viability of knockout mice. However, conventional drug screens have not identified a small molecule inhibitor for this activity. It has been suggested that it may be difficult to identify a good nonpeptide inhibitor for this enzyme with useful bioavailability in the brain (52). The enzymes responsible for cleavage of the BACE propeptide may be good drug targets for inhibiting BACE indirectly. In addition, proteolytic maturation of proBACE may play an important role in regulating BACE activity in the brain as well as in the pathogenesis of AD.

While this manuscript was under review, another paper showing that BACE maturation is mediated by several proprotein convertases in vitro was published in the Journal of Biological Chemistry (53). 
This study was supported by a grant 2000017 from the Institute for the Study of Aging to KS. The authors thank Dr. Terrone Rosenberry, Todd Golde, Christopher Eckman, Daniel Sevlever, and Meera Parasuraman for useful discussion and critical reading of the manuscript.

\section{REFERENCES}

1. Sinha, S., and Lieberburg, I. (1999) Cellular mechanisms of beta-amyloid production and secretion. Proc. Nat. Acad. Sci. USA 96, 11049-11053

2. Sisodia, S. S., and Price, D. L. (1995) Role of the beta-amyloid protein in Alzheimer's disease. FASEB J. 9, 366-370

3. Selkoe, D. J. (1991) The molecular pathology of Alzheimer's disease. Neuron 6, 487-498

4. Haass, C., and Selkoe, D. J. (1993) Cellular processing of beta-amyloid precursor protein and the genesis of amyloid beta-peptide. Cell 75, 1039-1042

5. Gandy, S., Caporaso, G., Buxbaum, J., Frangione, B., and Greengard, P. (1994) APP processing, A beta-amyloidogenesis, and the pathogenesis of Alzheimer's disease. Neurobiol. Aging 15, 253-256

6. Checler, F. (1995) Processing of the beta-amyloid precursor protein and its regulation in Alzheimer's disease. J. Neurochem. 65, 1431-1444

7. Shoji, M., Golde, T. E., Ghiso, J., Cheung, T. T., Estus, S., Shaffer, L. M., Cai, X. D., McKay, D. M., Tintner, R., Frangione, B., and Younkin, S. G. (1992) Production of the Alzheimer amyloid beta protein by normal proteolytic processing. Science 258, 126-129

8. Haass, C., Schlossmacher, M. G., Hung, A. Y., Vigo-Pelfrey, C., Mellon, A., Ostaszewski, B. L., Lieberburg, I., Koo, E. H., Schenk, D., Teplow, D. B., and Selkoe, D. J. (1992) Amyloid beta-peptide is produced by cultured cells during normal metabolism. Nature 359, 322-325

9. Seubert, P., Vigo-Pelfrey, C., Esch, F., Lee, M., Dovey, H., Davis, D., Sinha, S., Schlossmacher, M., Whaley, J., Swindlehurst, C., Lieberburg, I., and Shenk, D. (1992) Isolation and quantification of soluble Alzheimer's beta-peptide from biological fluids. Nature 359, 325-327

10. Suzuki, N., Cheung, T. T., Cai, X. D., Odaka, A., Otvos, L., Jr., Eckman, C., Golde, T. E., and Younkin, S. G. (1994) An increased percentage of long amyloid beta protein secreted by familial amyloid beta protein precursor (beta APP717) mutants. Science 264, 1336-1340

11. Younkin, S. G. (1998) The role of A beta 42 in Alzheimer's disease. J. Physiol. 92, 289292

12. Seubert, P., Oltersdorf, T., Lee, M. G., Barbour, R., Blomquist, C., Davis, D. L., Bryant, K., Fritz, L. C., Galasko, D., Thal, L. J., Lieberburg, I., and Schenk, D. B. (1993) Secretion 
of beta-amyloid precursor protein cleaved at the amino terminus of the beta-amyloid peptide. Nature 361, 260-263

13. Estus, S., Golde, T. E., Kunishita, T., Blades, D., Lowery, D., Eisen, M., Usiak, M., Qu, X., Tabira, T., Greenberg, B., and Younkin, S. G. (1992) Normal processing of the Alzheimer's disease amyloid beta protein precursor generates potentially amyloidogenic carboxyl-terminal derivatives. Science 255, 726-728

14. Haass, C., Lemere, C. A., Capell, A., Citron, M., Seubert, P., Schenk, D., Lannfelt, L., and Selkoe, D. J. (1995) The Swedish mutation causes early-onset Alzheimer's disease by beta-secretase cleavage within the secretory pathway. Nature Med. 1, 1291-1296

15. Yan, R., Bienkowski, M. J., Shuck, M. E., Miao, H., Tory, M. C., Pauley, A. M., Brashier, J. R., Stratman, N. C., Mathews, W. R., Buhl, A. E., Carter, D. B., Tomasselli, A. G., Parodi, L. A., Heinrikson, R. L., and Gurney, M. E. (1999) Membrane-anchored aspartyl protease with Alzheimer's disease beta-secretase activity. Nature 402, 533-537

16. Vassar, R., Bennett, B. D., Babu-Khan, Kahn, S., Mendiaz, E. A., Denis, P., Teplow, D. B., Ross, S., Amarante, P., Loeloff, R., Luo, Y., Fisher, S., Fuller, J., Edenson, S., Lile, J., Jarosinski, M. A., Biere, A. L., Curran, E., Burgess, T., Louis, J. C., Collins, F., Treanor, J., Rogers, G. , and Citron, M. (1999) beta-Secretase cleavage of Alzheimer's amyloid precursor protein by the transmembrane aspartic protease BACE. Science 286, 735-741

17. Sinha, S., Anderson, J. P., Barbour, R., Basi, G. S., Caccavello, R., Davis, D., Doan, M., Dovey, H. F., Frigon, N., Hong, J., Jacobson-Croak, K., Jewett, N., Keim, P., Knops, J., Lieberburg, I., Power, M., Tan, H., Tatsuno, G., Tung, J., Schenk, D., Seubert, P., Suomensaari, S. M., Wang, S., Walker, D., and John, V. (1999) Purification and cloning of amyloid precursor protein beta-secretase from human brain. Nature 402, 537-540

18. Lin, X., Koelsch, G., Wu, S., Downs, D., Dashti, A., and Tang, J. (2000) Human aspartic protease memapsin 2 cleaves the beta-secretase site of beta-amyloid precursor protein. Proc. Natl. Acad. Sci. USA 97, 1456-1460

19. Hussain, I., Powell, D., Howlett, D. R., Tew, D. G., Meek, T. D., Chapman, C., Gloger, I. S., Murphy, K. E., Southan, C. D., Ryan, D. M., Smith, T. S., Simmons, D. L., Walsh, C. Dingwall, F. S., and Christie, G. (1999) Identification of a novel aspartic protease (Asp 2) as beta-secretase. Mol. Cell. Neurosci. 14, 419-427

20. Farzan, M., Schnitzler, C. E., Vasilieva, N., Leung, D., and Choe, H. (2000) BACE2, a beta-secretase homolog, cleaves at the beta site and within the amyloid-beta region of the amyloid-beta precursor protein. Proc. Natl. Acad. Sci. USA 97, 9712-9717

21. Buxbaum, J. D., Gandy, S. E., Cicchetti, P. Ehrlich, M. E., Czernik, A. J., Fracasso, R. P., Ramabhadran, T. V., Unterbeck, A. J., and Greengard, P. (1990) Processing of Alzheimer beta/A4 amyloid precursor protein: modulation by agents that regulate protein phosphorylation. Proc. Natl. Acad. Sci. USA 87, 6003-6006 
22. Sambamurti, K., Sevlever, D., Koothan, T., Refolo, L. M., Pinnix, I., Gandhi, S., Onstead, L., Younkin, L., Prada, C. M., Yager, D., Ohyagi, Y., Eckman, C. B., Rosenberry, T. L., and Younkin, S. G. (1999) Glycosylphosphatidylinositol-anchored proteins play an important role in the biogenesis of the Alzheimer's amyloid beta-protein. J. Biol. Chem. 274, 26810-26814

23. Esch, F. S., Keim, P. S., Beattie, E. C., Blacher, R. W., Culwell, A. R., Oltersdorf, T., McClure, D., and Ward, P. J. (1990) Cleavage of amyloid beta peptide during constitutive processing of its precursor. Science 248, 1122-1124

24. Arribas, J., Coodly, L., Vollmer, P., Kishimoto, T. K., Rose-John, S., and Massague, J. (1996) Diverse cell surface protein ectodomains are shed by a system sensitive to metalloprotease inhibitors. J. Biol. Chem. 271, 11376-11382

25. Buxbaum, J. D., Liu, K. N., Luo, Y., Slack, J. L., Stocking, K. L., Peschon, J. J., Johnson, R. S., Castner, B. J., Cerretti, D. P., and Black, R. A. (1998) Evidence that tumor necrosis factor alpha converting enzyme is involved in regulated alpha-secretase cleavage of the Alzheimer amyloid protein precursor. J. Biol. Chem. 273, 27765-27767

26. Lammich, S., Kojro, E., Postina, R., Gilbert, S., Pfeiffer, R., Jasionowski, M., Haass, C., and Fahrenholz, F. (1999) Constitutive and regulated alpha secretase cleavage of Alzheimer's amyloid precursor protein by a disintegrin metalloprotease. Proc. Natl. Acad. Sci. USA 96, 3922-3927

27. Pinnix, I., Musunuru, U., Tun, H., Sridharan, A., Golde, T. E., Eckman, C., Ziani-Cherif, C., Onstead, L., and Sambamurti, K. (2001) A novel gamma secretase assay based on detection of the putative $C$-terminal fragment-gamma of APP. J. Biol. Chem. 276, 481-487

28. Esler, W. P., Taylor, K., Ostaszewski, L., Diehl, T. S., Moore, C. L., Tsai, J. Y., Rahmati, T., Xia, W., Selkoe, D. J., and Wolfe, M. S. (2000) Transition-state analogue inhibitors of gamma-secretase bind directly to presenilin-1. Nature Cell. Biol. 2, 428-434

29. Selkoe, D. J., and Wolfe, M. S. (2000) In search of gamma-secretase: presenilin at the cutting edge. Proc. Natl. Acad. Sci. USA 97, 5690-5692

30. Li, Y. M., Xu, M., Lai, M. T., Huang, Q., Castro, J. L., DiMuzio-Mower, J., Harrison, T., Lellis, C., Nadin, A., Neduvelil, J. G., Register, R. B., Sardana, M. K., Shearman, M. S., Smith, A. L., Shi, X. P., Yin, K. C., Shafer, J. A., and Gardell, S. J. (2000) Photoactivated gamma-secretase inhibitors directed to the active site covalently label presenilin 1. Nature 405, 689-694

31. Zhang, Z., Nadeau, P., Song, W., Donoviel, D., Yuan, M., Bernstein, A., and Yankner, B. A. (2000) Presenilins are required for gamma-secretase cleavage of beta-APP and transmembrane cleavage of Notch-1. Nature Cell Biol. 2, 463-465 
32. Herreman, A., Serneels, L., Annaert, W., Collen, D., Schoonjans, L., and De Strooper, B. (2000) Total inactivation of gamma-secretase activity in presenilin-deficient embryonic stem cells. Nature Cell Biol. 2, 461-462

33. Cai, H., Wang, Y., Wen, H., Nathans, J., Price, D. L., and Wong, P. C. (2000) Physiological role of beta-site APP-cleaving enzyme (BACE): Generation and characterization of BACE-deficient mice. Soc. Neurosci. 30th Annual Meeting November $4-$ 9,2000

34. Creemers, J., Dominguez, D., Plets, E., Serneels, L., Taylor, N., Multhaup, G., Craessaerts, K., Annaert, W., and De Strooper, B. (2001) Processing of beta-secretase (BACE) by furin and other members of the proprotein convertase family. J. Biol. Chem. 276, $4211-4217$

35. Ermolieff, J., Loy, J., Koelsch, G., and Tang, J. (2000) Proteolytic activation of recombinant pro-memapsin 2 (pro-beta-secretase) studied with new fluorogenic substrates. Biochemistry 39, 12450-12456; 16263

36. Shi, X., Chen, E., Yin, K., Na, S., Garsky, V., Lai, M., Li, Y., Platchek, M., Tang, R., Thiebeau, J., Wood, T., Shafer, J., and Gardell, S. (2000) The pro domain of $\{$ beta $\}$-secretase does not confer strict zymogen-like properties but does assist proper folding of the protease domain. J. Biol. Chem. 276, 10366-10373

37. Seidah, N., and Chretien, M. (1999) Proprotein and prohormone convertases: a family of subtilases generating diverse bioactive polypeptides. Brain Res. 848, 45-62

38. Zhou, A., Webb, G., Zhu, X., and Steiner, D. (1999) Proteolytic processing in the secretory pathway. J. Biol. Chem. 274, 20745-20748

39. Ohnishi, Y., Shioda, T., Nakayama, K., Iwata, S., Gotoh, B., Hamaguchi, M., and Nagai, Y. (1994) A furin-defective cell line is able to process correctly the GP160 of human immunodeficiency virus type 1. J. Virol. 68, 4075-4079

40. Moehring, T., and Moehring, J. (1977) Selection and characterization of cells resistant to diphtheria toxin and Pseudomonas exotoxin A: presumptive translational mutants. Cell 11, $447-454$

41. Spence M. J., Sucic, J. F., Foley, B. T., and Moehring, T. J. (1995) Analysis of mutations in alleles of the fur gene from an endoprotease-deficient Chinese hamster ovary cell strain. Somat. Cell. Mol. Genet. 21, 1-18

42. Sucic, J., Spence, M., and Moehring, T. (1998) Structural and functional analysis of the protein products derived from mutant fur alleles in an endoprotease-deficient Chinese hamster ovary cell strain. Somat. Cell. Mol. Genet. 24, 75-90 
43. Sucic, J., Moehring, J., Inocencio, N., Luchini, J., and Moehring, T. (1999) Endoprotease PACE4 is Ca2+-dependent and temperature-sensitive and can partly rescue the phenotype of a furin-deficient cell strain. Biochem. J. 339, 639-647

44. Inocencio, N., Sucic, J., Moehring, J., Spence, M., and Moehring, T. (1997) Endoprotease activities other than furin and PACE4 with a role in processing of HIV-I GP160 glycoproteins in CHO-K1 cells. J. Biol. Chem. 272, 1344-1348

45. Kim, S. H., Wang, R., Gordon, D. J., Bass, J., Steiner, D. F., Lynn, D.G., Thinakaran, G., Meredith, S.C., and Sisodia, S.S. (1999) Furin mediates enhanced production of fibrillogenic ABri peptides in familial British dementia. Nat. Neurosci. 2, 984-988

46. Sambamurti, K., Shioi, J., Anderson, J. P., Pappolla, M. A., and Robakis, N. K. (1992) Evidence for intracellular cleavage of the Alzheimer's amyloid precursor in PC12 cells. $J$. Neurosci. Res. 33, 319-329

47. Harlow, E., and Lane, D. (1988) Antibodies, A Laboratory Manual. Cold Spring Harbor: Cold Spring Harbor, New York

48. Bennett, B., Denis, P., Haniu, M., Teplow, D. B., Kahn, S., Louis, J. C., Citron, M., and Vassar, R. (2000) A furin-like convertase mediates propeptide cleavage of BACE, the Alzheimer's beta-secretase. J. Biol. Chem. 275, 37712-37717

49. Huse, J., Pijak, D., Leslie, G., Lee, V., and Doms, R. (2000) Maturation and endosomal targeting of beta-site amyloid precursor protein-cleaving enzyme: the Alzheimer's disease beta-secretase. J. Biol. Chem. 275, 33729-33737

50. Capell, A., Steiner, H., Willem, M., Kaiser, H., Meyer, C., Walter, J., Lammich, S., Multhaup, G., and Haass, C. (2000) Maturation and pro-peptide cleavage of beta-secretase. $J$. Biol. Chem. 275, 30849-30854

51. Duguay, S., Milewski, W., Young, B., Nakayama, K., and Steiner, D. (1997) Processing of wild-type and mutant proinsulin-like growth factor-IA by subtilisin-related proprotein convertases. J. Biol. Chem. 272, 6663-6670

52. Hong, L., Koelsch, G., Lin, X., Wu, S., Terzyan, S., Ghosh, A. K., Zhang, X.C., and Tang, J. (2000) Structure of the protease domain of memapsin 2 (beta-secretase) complexed with inhibitor. Science 290, 150-153

53. Benjannet, S., Elagoz, A., Wickham, L., Mamarbachi, M., Munzer, J. S., Basak, A., Lazure, C., Cromlish, J. A., Sisodia, S., Checler, F., Chretien, M., and Seidah, N. G. (2001) Post-translational processing of $\beta$-secretase (BACE) and its ectodomain shedding: the proand transmembrane/cytosolic domains affect its cellular activity and amyloid $\mathrm{A} \beta$ production. J. Biol. Chem. 276, 10879-10887 
Fig. 1

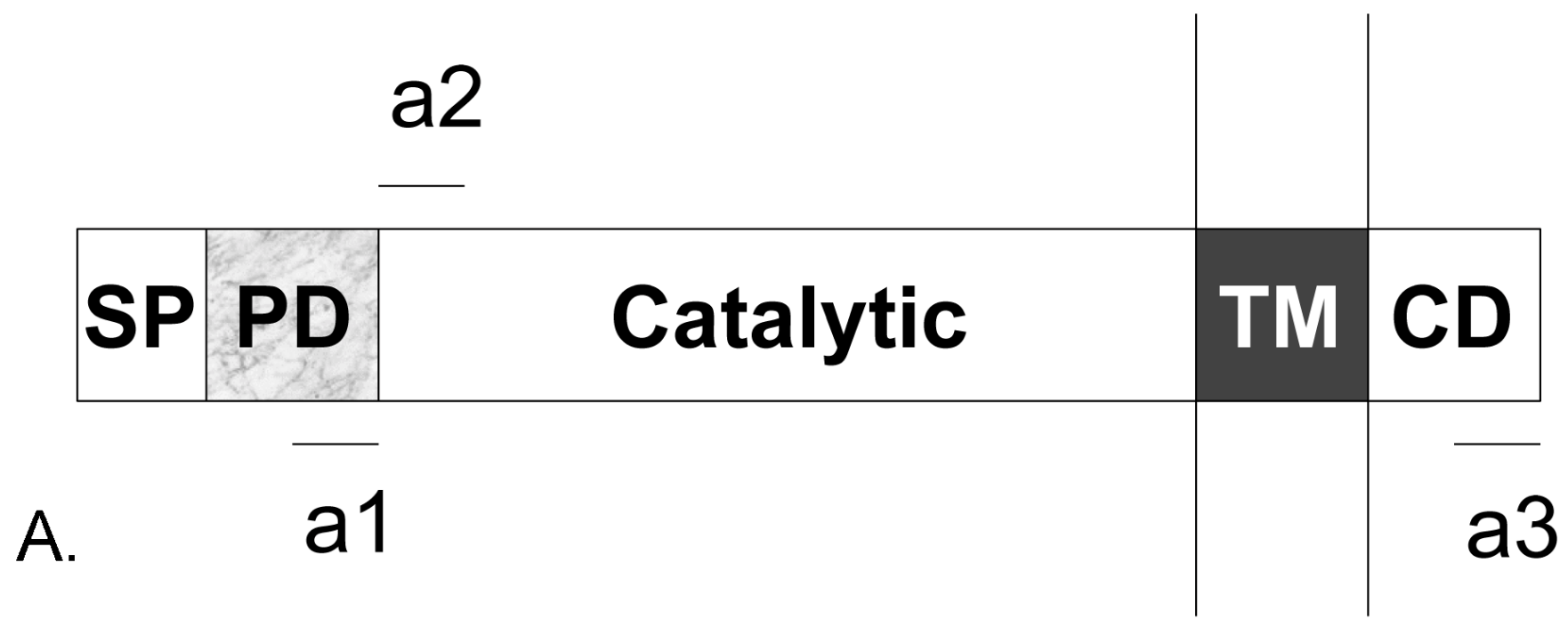

\section{RPE.40 RPE-BACE CHO-BACE $\begin{array}{lllllllll}1 & 2 & 3 & 4 & 5 & 6 & 7 & 8 & 9\end{array}$}

B. BACE26-45

C. BACE46-65

D. BACECT15

Figure 1. Three antibodies specifically detect BACE. Panel A is a schematic diagram of BACE, which is a type-1 integral membrane glycoprotein with a signal sequence (SP; residues 1-21), a short prodomain that is missing in the mature protein (PD, residues 22-45), a catalytic luminal domain, a single transmembrane domain, and a short cytoplasmic tail. The luminal catalytic domain contains two consensus aspartyl protease motifs and four $\mathrm{N}$-glycosylation sites (not shown). Antibodies were raised against selected regions as follows: a1, BACE $26-45, \mathrm{PD}$; a2, $\mathrm{BACE}$ 46-65, $N$-terminus of catalytic domain; and a3, BACE $\mathrm{CT15}_{15}$, the $C$-terminal 15 residues of the cytoplasmic tail. Lysates from untransfected control RPE.40 (lanes 1-3) and three independent stable transfectants expressing BACE in RPE.40 (RPE-BACE; lanes 46) and CHO-K1 (CHO-BACE; lanes 7-9) were separated on 10\% NuPAGE gels as described in Experimental Procedures. Western blotting shows the relative signal of the 75-kDa BACE band detected using antibodies $\mathrm{BACE}_{26-45}$, $\mathrm{BACE}_{46-65}$, and $\mathrm{BACE}_{\mathrm{CT} 15}$ in panels $\mathbf{B}, \mathbf{C}$, and $\mathbf{D}$, respectively. 
Fig. 2

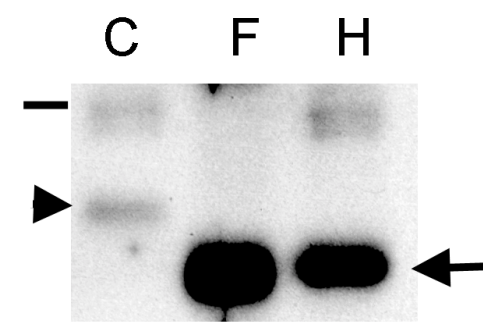

A. BACE $26-45$

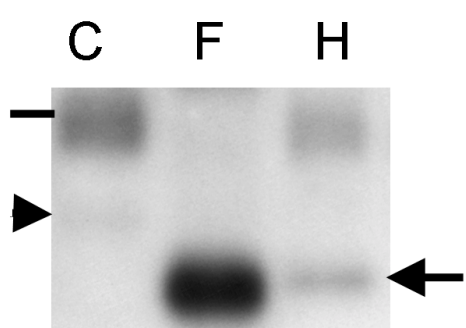

B. BACE 46-65

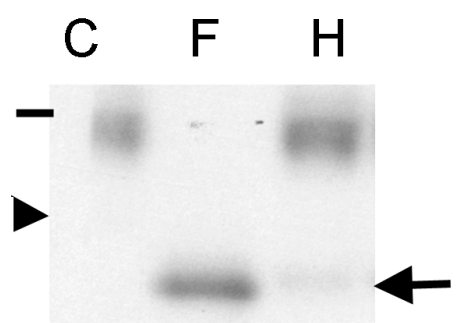

C. BACE CT15

Figure 2. BACE is post-translationally modified with $N$-linked sugars. Equal protein from control (C)-, Endo F (F)-, and Endo $\mathrm{H}(\mathrm{H})$-treated lysates of RPE.40-BACE were examined by Western blotting with BACE $\mathrm{B}_{26-45}\left(\mathrm{Panel} \mathrm{A}_{\mathrm{A}}\right), \mathrm{BACE}_{46-}$ ${ }_{65}$ (Panel B), and BACE ${ }_{\mathrm{CT} 15}$ (Panel C). The 75-kDa band is indicated by a dash and the 65-kDa band by an arrowhead on the left of each panel. These bands represent the fully glycosylated (75-kDa) and core glycosylated (65-kDa) BACE protein. Endo $\mathrm{F}$ and Endo $\mathrm{H}$ treatment generates a shorter 50-kDa deglycosylated BACE band, indicated by the arrow on the right of each panel. The 50-kDa deglycosylated band is more intense than the $65+75 \mathrm{kDa}$ bands in the control lanes of panels $\mathrm{A}$ and $\mathrm{B}$, which suggests that the $N$-terminal domain detected by the $\mathrm{BACE}_{26-45}$ and $\mathrm{BACE}_{46-65}$ antibodies is partially masked by glycosylation. Note that Endo F converts both bands to the 50-kDa deglycosylated form, whereas Endo $\mathrm{H}$ only cleaves the 65-kDa core glycosylated form. 
Fig. 3

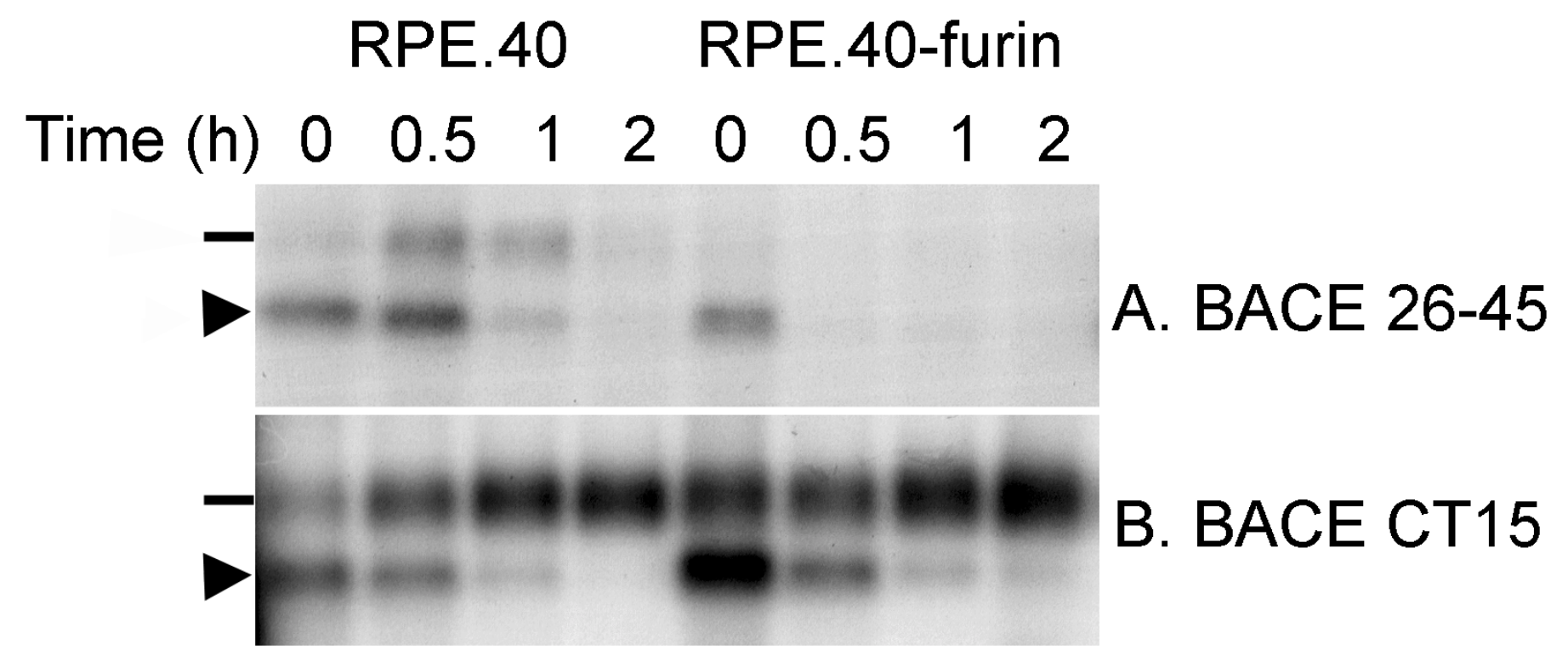

Figure 3. ProBACE is rapidly turned over in RPE.40 cells, but total BACE is stable. A pulse-chase study was conducted in RPE.40 cells stably transfected with BACE (RPE.40) and cotransfected with furin (RPE.40-furin) as indicated. Immunoprecipitates show turnover of proBACE using $\mathrm{BACE}_{26-45}(\mathbf{A})$ and total BACE using BACE $\mathrm{CT}_{15}(\mathbf{B})$. The $65-\mathrm{kDa}$ core glycosylated band (arrowhead) at 0-time matures into the larger $75-\mathrm{kDa}$ form (dash) after elaboration of sugars during the chase period of $0.5-2 \mathrm{~h}$. 
Fig. 4
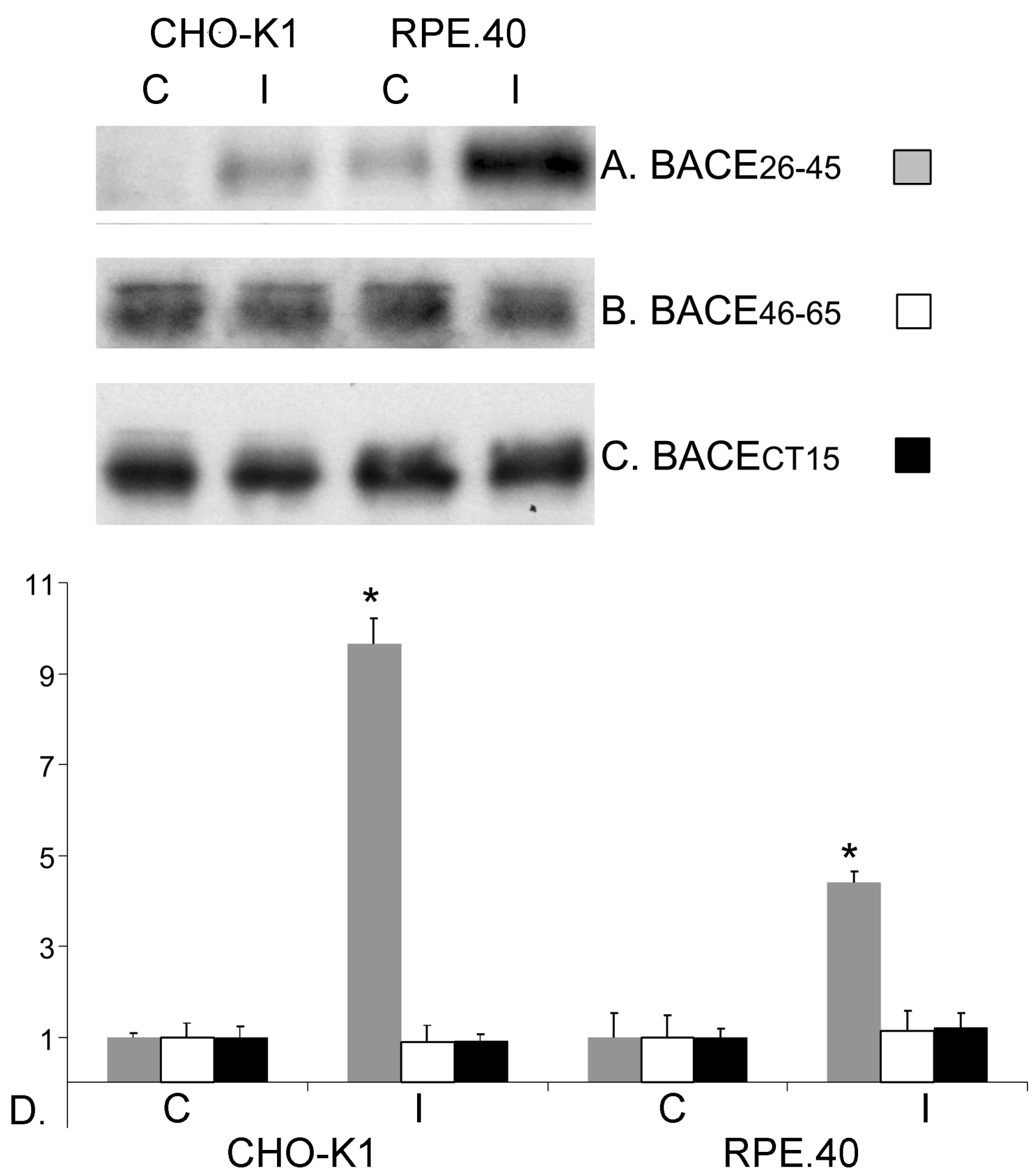

Figure 4. A proprotein convertase inhibitor increases proBACE in RPE.40. Transfected CHO-K1 and RPE.40 cultures expressing BACE were treated with 50- $\mu \mathrm{M} \mathrm{d}$-RVKR-CMK (I) for $4 \mathrm{~h}$ at $37^{\circ} \mathrm{C}$ and compared with vehicle control (C), and BACE was examined by Western blotting with BACE ${ }_{26-45}$ (Panel A), BACE $46-65$ (Panel B), and BACE BT15 $_{\text {(Panel }}$ C). Panel D presents the mean \pm SD of the 75-kDa band detected by BACE ${ }_{26-45}$ (gray bars), BACE $46-65$ (clear bars), and $\mathrm{BACE}_{\mathrm{CT} 15}$ (black bars) quantified by densitometry of three independent samples. ( $* P<0.05$ by two-tailed $t$ test.) 
Fig. 5

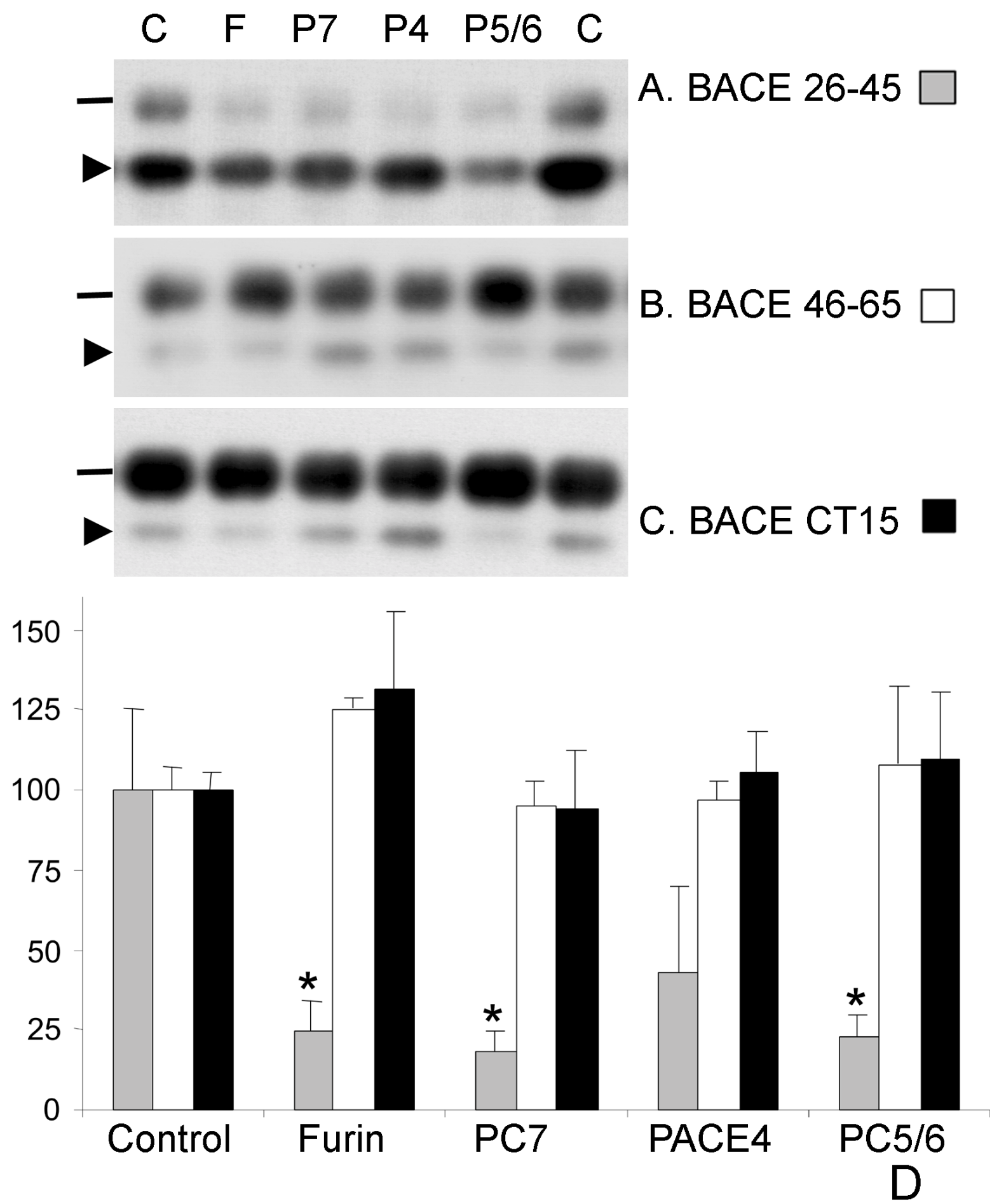

Figure 5. Furin, PC7, PACE4, and PC5/6 increase processing of proBACE in vivo. RPE.40 was transfected with vector control (C), furin (F), PC7 (P7), PACE4 (P4), and PC5/6 (P5/6) using Lipofectamine reagent (Invitrogen, Carlsbad, $\mathrm{CA}$ ), as described by the manufacturer. Western blots show proBACE signal detected with BACE $26-45$ (Panel A). Total BACE was detected with BACE ${ }_{46-65}\left(\right.$ Panel B) and BACE ${ }_{\text {CT15 }}$ (Panel C). The dash points to the 75-kDa band and the arrowhead to the $65-\mathrm{kDa}$ band. Panel $\mathbf{D}$ is a graph showing the quantification of the $75-\mathrm{kDa}$ band from three to six independent samples for each condition. Scanned images were quantified as in Figure 4 . $\left({ }^{*} P<0.05\right.$ by two-tailed $t$ test.) 